\title{
New Cinchona Oximes Evaluated as Reactivators of Acetylcholinesterase and Butyrylcholinesterase Inhibited by Organophosphorus Compounds
}

\author{
Maja Katalinić ${ }^{1}$, Antonio Zandona ${ }^{1}$, Alma Ramić ${ }^{2}$, Tamara Zorbaz ${ }^{1}$, Ines Primožič ${ }^{2, *}$ \\ and Zrinka Kovarik 1,* \\ 1 Institute for Medical Research and Occupational Health, POB 291, HR-10001 Zagreb, Croatia; \\ mkatalinic@imi.hr (M.K.); azandona@imi.hr (A.Z.); tzorbaz@imi.hr (T.Z.) \\ 2 Department of Chemistry, Faculty of Science, University of Zagreb, HR-10001 Zagreb, Croatia; \\ alma.ramic@gmail.com \\ * Correspondence: ines.primozic@chem.pmf.hr (I.P.); zkovarik@imi.hr (Z.K.); Tel.: +385-1-4606-408 (I.P.); \\ $+385-1-4682-555$ (Z.K.)
}

Received: 30 June 2017; Accepted: 19 July 2017; Published: 22 July 2017

\begin{abstract}
For the last six decades, researchers have been focused on finding efficient reactivators of organophosphorus compound (OP)-inhibited acetylcholinesterase (AChE) and butyrylcholinesterase (BChE). In this study, we have focused our research on a new oxime scaffold based on the Cinchona structure since it was proven to fit the cholinesterases active site and reversibly inhibit their activity. Three Cinchona oximes ( $\mathrm{C} 1, \mathrm{C} 2$, and $\mathrm{C} 3)$, derivatives of the 9-oxocinchonidine, were synthesized and investigated in reactivation of various OP-inhibited AChE and BChE. As the results showed, the tested oximes were more efficient in the reactivation of $\mathrm{BChE}$ and they reactivated enzyme activity to up to $70 \%$ with reactivation rates similar to known pyridinium oximes used as antidotes in medical practice today. Furthermore, the oximes showed selectivity towards binding to the BChE active site and the determined enzyme-oxime dissociation constants supported work on the future development of inhibitors in other targeted studies (e.g., in treatment of neurodegenerative disease). Also, we monitored the cytotoxic effect of Cinchona oximes on two cell lines Hep G2 and SH-SY5Y to determine the possible limits for in vivo application. The cytotoxicity results support future studies of these compounds as long as their biological activity is targeted in the lower micromolar range.
\end{abstract}

Keywords: nerve agents; pesticides; alkaloids; cytotoxicity; reversible inhibition

\section{Introduction}

Organophosphorus compounds (OPs), commonly used as pesticides, but also as an insidious threat in terrorism, are covalent inhibitors of the enzymes acetylcholinesterase (AChE, EC 3.1.1.7) and butyrylcholinesterase (BChE, EC 3.1.1.8) phosphylating their active center serine. The inhibition in vivo triggers a cholinergic crisis, resulting from the accumulation of acetylcholine and overstimulation of receptors in synapses. Therefore, human exposure to these hazardous compounds results in acute poisoning manifested by salivation, tremors, respiratory paralysis, hypotension, and, with more extreme exposure, death [1].

Efficacy of the oxime therapy, typically 2-PAM, obidoxime or HI-6, combined with atropine and an anticonvulsant, is still limited [2,3]. Though the symptoms of poisoning will be somewhat attenuated by atropine and an anticonvulsant, the applied oximes will not be equally effective in reactivating AChE inhibited by several nerve agents [1-3], and with that the cholinergic crisis will persist leading to the unwanted consequences. In addition, inhibitory OPs remain in different body compartments permitting redistribution into the plasma, where they are capable of inhibiting or re-inhibiting active 
AChE at target sites [4]. The effectiveness of oxime-assisted reactivation is primarily attributed to the nucleophilic displacement rate of organophosphates, but efficiency varies with the structure of the bound organophosphate [5-7]. This fact has led to the synthesis and investigation of numerous oximes in the past sixty years. One direction for an efficiency improvement has led to the design of advanced oximes with a peripheral anionic site (PAS) moiety for anchoring the oxime molecule at the PAS [8,9]. Recent studies have also focused on the development of uncharged species to improve delivery to the central nervous system [9-12].

This paper reports on the synthesis of three derivatives of Cinchona oxime compounds. Some derivatives of cinchonidine have been identified as inhibitors of cholinesterases fitting their active site $[13,14]$. Therefore, we found them interesting for oxime moiety addition and their evaluation as reactivators of human AChE (hAChE) and BChE (hBChE) inhibited by OPs. To test this scaffold's properties in the design of potential antidotes, we synthesized and prepared three oximes (C1, C2 and $\mathrm{C} 3$ ), bearing the oxime moiety in the central linker and differing in the side chain of the quinuclidine ring (Figure 1). We evaluated their reactivation potential in VX, sarin, cyclosarin, tabun and paraoxon poisoning as well as determined their affinity for reversible binding to AChE and BChE. Furthermore, we also tested their cytotoxicity on two cell lines, hepatocytes (Hep G2) and neurones (SH-SY5Y), to assess their potential to be used in in vivo application.

\section{Results and Discussion}

Cinchonidin-9-one was prepared by oxidizing cinchonidine with potassium $t$-butoxide and benzophenone in toluene [15]. The reaction of ketone with hydroxylamine hydrochloride in ethanol resulted in the Cinhona 9-oxime (C1) as an off-white solid in good yield. The nitrogen atom of the quinuclidine part of the molecule was quaternized with methyl iodide (C2) or benzyl bromide (C3) in dry acetone (Figure 1). All compounds were prepared in good yields and were characterized by standard analytical spectroscopy methods (1D and 2D NMR, IR, MS). Robins studied tautomerism of cinchonidine-9-one in polar solvents and concluded that it undergoes mutarotation forming a mixture of $8 S$ - and $8 R$-epimers, which can be seen in the ${ }^{13} \mathrm{C}-\mathrm{NMR}$ spectrum [15]. During the synthesis of our compounds, in reaction with hydroxylamine in ethanol, epimerization at position eight of the quinuclidine ring occurred as expected, with the ratio of epimers $8 R: 8 S=70: 30$ for $C 1$. Furthermore, epimerization was observed during the synthesis of $C 2(8 R: 8 S=60: 40)$ and $C 3(8 R: 8 S=50: 50)$. Thus, upon resting in a polar solution, additional resonances in ${ }^{1} \mathrm{H}$ - and ${ }^{13} \mathrm{C}-\mathrm{NMR}$ spectra of all compounds were observed. The same effect was detected for oximes due to the possibility of forming syn- and anti-isomers. To confirm these findings, quantum chemical for all possible isomers of Cinchona 9-ketone and 9-ketoximes were carried out. For each compound geometry optimizations and harmonic frequency calculations using density functional theory (B3LYP/6-311++G(d,p)) were performed. All harmonic frequencies were real confirming that the obtained structures are local minima. Subsequently, magnetic isotropic shielding was calculated at the same level of the theory. NMR spectra were estimated and compared to the experimentally obtained one. Observed differences in the set of NMR data for each C8-epimer of compound C1 which are separated chromatographically, were compared to the calculated values. The most useful differences detected in experimentally obtained data were assigned to carbon atoms C2 and C6, (Materials and Methods and Supplemental Materials) in ${ }^{13}$ C-NMR spectra, and to hydrogen atom $\mathrm{H} 10$ in ${ }^{1} \mathrm{H}-\mathrm{NMR}$ spectra (Materials and Methods and Supplemental Materials). DFT calculation enabled the assignation of spectra in respect of C8-tautomers by comparing relative values of chemical shifts for each atom in the present species, Tables S1-S3.

Oximes were profiled in the reactivation of hAChE inhibited by VX, sarin, cyclosarin, tabun and paraoxon using $0.1 \mathrm{mM}$ oximes. This concentration is widely used in the screening of oximes' reactivation potency and by using this concentration we were able to directly compare our results with published literature data $[9,16,17]$. Also, this concentration is considered applicable to humans $[1,2]$. The obtained results for the hAChE reactivation are summarized in Figure 2. As our results indicate, the maximal achieved reactivation was less than $25 \%$, and the overall low hAChE reactivation potency 
was irrespective of the structure of an oxime or a bound organophosphorus compound, which maybe implies low binding affinity to the OP-enzyme complex due to spatial constraints within the narrow active site gorge of hAChE. These results also indicate that the positioning of these three compounds is unfavorable for reactivation within the hAChE's active site. Moreover, in silico and in vitro determined high $\mathrm{pK}$ a values (Figure 3 ) of the oxime group could be correlated with lower nucleophilicity of Cinchona oximes, since expected concentration of the more nucleophilic oximate ion at $\mathrm{pH} 7.4$ is low (about $2-3 \%$ of total compound concentration).
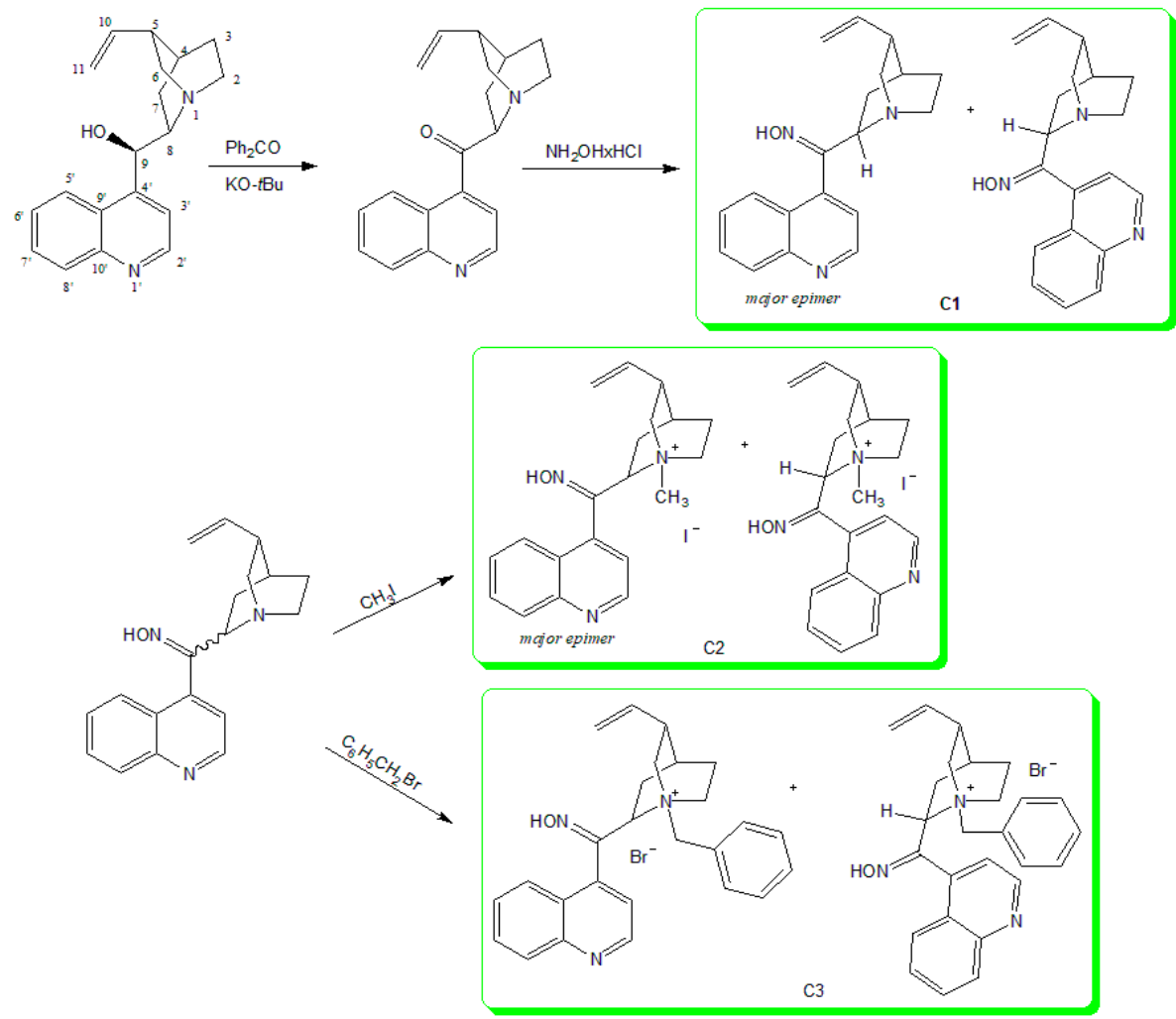

Figure 1. Synthesis of Cinchona derivatives starting from cinchonidine.

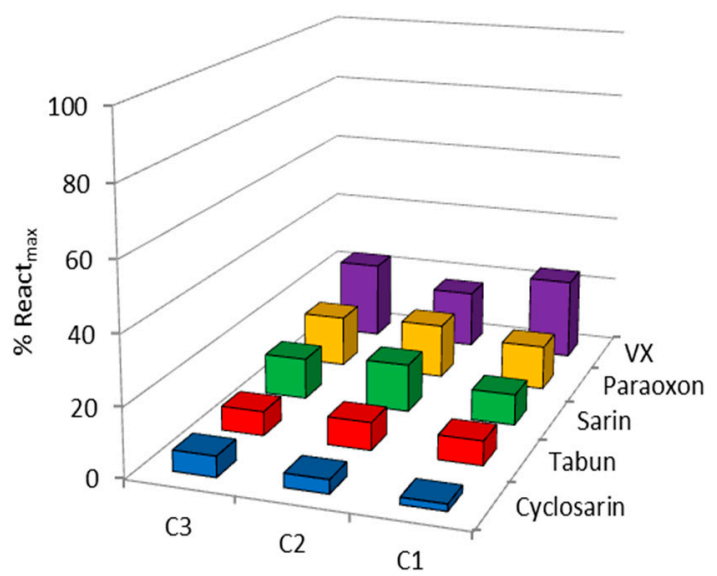

Figure 2. Screening of organophosphorus compound (OP)-inhibited human acetylcholinesterase (hAChE) reactivation by $0.1 \mathrm{mM}$ oximes $\mathrm{C} 1, \mathrm{C} 2$ and $\mathrm{C} 3$ at $25{ }^{\circ} \mathrm{C}$. Results in terms of the maximal obtained reactivation percentage within $23 \mathrm{~h}$ are presented as a mean of two to three experiments (experimental deviation was less than 10\%). 
In the case of $\mathrm{hBChE}$ reactivation, the results were more promising; the maximal obtained reactivation rose up to $70 \%$ (Figure 4 and Figure S1). This was especially pronounced in the reactivation of sarin-inhibited $\mathrm{BChE}$ by oximes $\mathrm{C} 2$ and $\mathrm{C} 3$. The observed reactivation rate constants, $k_{\mathrm{obs}}$, were also evaluated where possible, in other words, where the observed reactivation exceeded 40\% (Figure S1). The results are summarized in Table 1 . As can be seen, the absence of a permanent charge in C1 did not benefit the reactivation and yielded the weakest results. This is contrary to other studies that showed a potential of the uncharged oximes in $\mathrm{hBChE}$ reactivation $[8,16]$. On the other hand, oxime $\mathrm{C} 2$ stood out as the most active against all of the OPs. Though the calculated rate constants should be much higher if one considers future application of this oxime in therapy/pretreatment, such a C2 Cinchona scaffold seems to be promising for the design of a long-desired universal reactivator for $\mathrm{hBChE}$ reactivation. According to recent results on $\mathrm{hBChE}$ reactivation, several pyridinium, imidazolium and even non-pyridinium oximes were pointed out as promising but still showed selectivity towards different OPs [8,17-21]. Although proper investigation of oximes as reactivators requires the determination of time- and concentration-dependent reactivation to give insight into reactivity and affinity, we were not able to test a wider oxime concentration range due to the observed strong affinity of uninhibited $\mathrm{hBChE}$ for these oximes (especially seen for oxime C3 wherefore $0.05 \mathrm{mM}$ was used in reactivation tests). However, we suppose that the additional modification of the Cinchona 9-oxime structure tuning the affinity and efficacy (e.g., towards lowering the $\mathrm{p} K_{\mathrm{a}}$ of the oxime group) could result in an even better reactivation outcome.

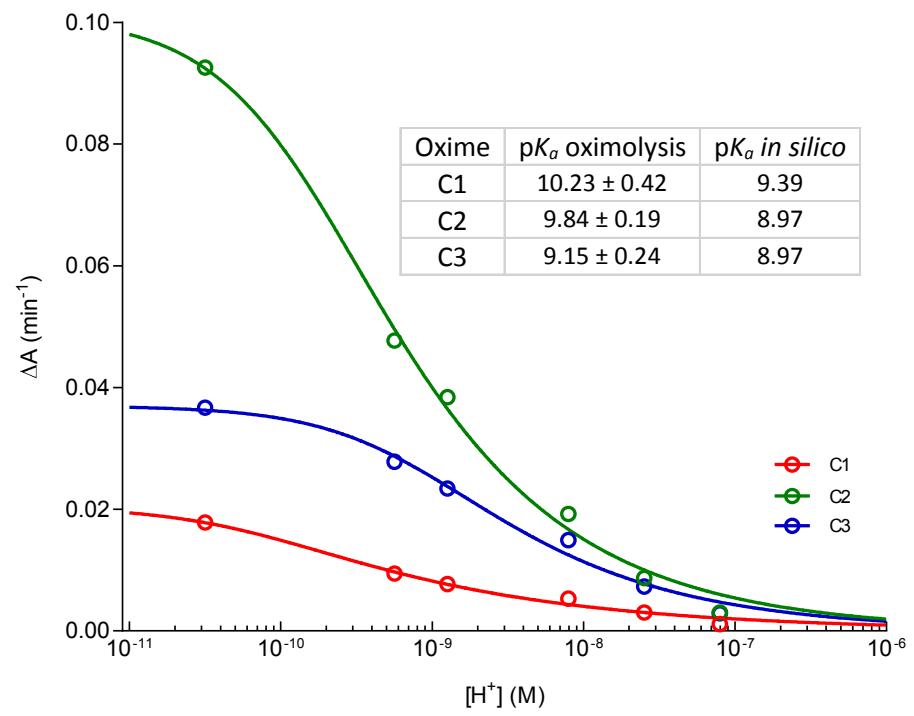

Figure 3. $\left[\mathrm{H}^{+}\right]$-dependence of oximolysis rate for $\mathrm{C} 1, \mathrm{C} 2$ and $\mathrm{C} 3$ oximes $(0.1 \mathrm{mM})$ and their in vitro and in silico determined $\mathrm{p} K_{\mathrm{a}}$ values. Acid dissociation constant $\left(K_{\mathrm{a}}\right)$ of the oxime group was determined by measuring the degradation of substrate acetylthiocholine $(1 \mathrm{mM})$ by $100 \mu \mathrm{M}$ oxime at $412 \mathrm{~nm}$ and in $\mathrm{pH}$ range 4.4-11.3 and was calculated using the Equation (1) (see Section 3.4). 


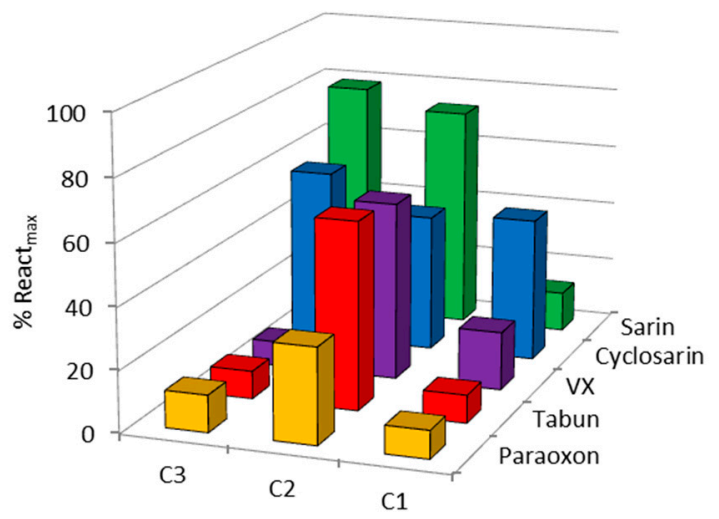

Figure 4. Screening of OP-inhibited human butyrylcholinesterase (hBChE) reactivation by $0.1 \mathrm{mM}$ oximes $\mathrm{C} 1, \mathrm{C} 2$ and $0.05 \mathrm{mM} \mathrm{C} 3$ at $25^{\circ} \mathrm{C}$. Results in terms of maximal obtained reactivation percentage within $22-24 \mathrm{~h}$ are presented as a mean of two to three experiments (experimental deviation was less than $10 \%)$.

Table 1. Screening of OP-inhibited hBChE reactivation by $0.1 \mathrm{mM}$ oximes $\mathrm{C} 1, \mathrm{C} 2$ and $0.05 \mathrm{mM}$ oxime C3. Observed reactivation rate constants $\left(k_{\text {obs }}\right)$, maximal reactivation (React $t_{\max }$ ) obtained in time $(t)$ are presented as the mean value of two experiments.

\begin{tabular}{ccccc}
\hline OP & Oxime & $\boldsymbol{k}_{\text {obs }}\left(\mathbf{m i n}^{-\mathbf{1}}\right)$ & React $_{\text {max }}(\mathbf{\%})$ & $\boldsymbol{t} \mathbf{( h )}$ \\
\hline \multirow{5}{*}{ VX } & C1 & - & 20 & 24 \\
& C2 & 0.0064 & 60 & 24 \\
& C3 & - & 15 & 22 \\
Sarin & HI-6 & 0.0356 & 85 & 2.5 \\
& C1 & - & 10 & 24 \\
& C2 & 0.0024 & 70 & 24 \\
& C3 & 0.0010 & 65 & 22 \\
Cyclosarin & HI-6 & 0.0113 & 98 & 24 \\
& C1 & 0.0008 & 45 & 24 \\
& C2 & 0.0040 & 45 & 24 \\
& C3 & - & 35 & 22 \\
Paraoxon & HI-6 & 0.0260 & 70 & 24 \\
& C1 & - & 10 & 24 \\
& C2 & - & 30 & 24 \\
& C3 & - & 15 & 22 \\
Tabun & Obidoxime & 0.0020 & 60 & 24 \\
& C1 & - & 10 & 24 \\
& C2 & 0.0015 & 60 & 24 \\
& C3 & - & 15 & 22 \\
\hline \multirow{5}{*}{ K117 } & 0.0095 & 67 & 24 \\
\hline
\end{tabular}

The observed effect prompted us to evaluate these oximes as reversible inhibitors of hAChE and $\mathrm{hBChE}$. The obtained results are summarized in Table 2 and presented as Hunter-Downs plots in Figure 5. The oximes inhibited both cholinesterases in micromolar range but showed a strong preference for binding to hBChE. This confirmed previous studies on similar compounds [13,14] but also indicated that the addition of the oxime moiety did not influence their ability to bind to the cholinesterases active site. Moreover, the evaluated dissociation inhibition constants $\left(K_{\mathrm{i}}\right)$ were higher than those published for pyridinium oximes and hAChE [22-24], and were 10-100-fold lower for pyridinium and imidazolium oximes and $\mathrm{hBChE}[17,25]$.

The experimental data presented in terms of the Hunter-Downs plot (Figure 5) enabled the estimation of a binding mode for the tested oximes. In such a plot, possible competitive or 
non-competitive reversible inhibition is indicated by a slope value: if inhibition is competitive, the slope of the plot is $>>0$; if non-competitive, the slope is zero [26]. In the case of cholinesterases, and due to the presence of the catalytic and the allosteric part of the specific active site structure, a mixed type inhibition is possible too. The type of inhibition could be confirmed by the evaluated enzyme-substrate dissociation constant $K_{\mathrm{S}}$ (X-intercept in the Hunter-Downs plot) which corresponds to the Michaelis constant $\left(K_{\mathrm{M}}\right)$. Values closer to the $K_{\mathrm{M}}(0.05 \mathrm{mM})$ will indicate a competitive type of reversible inhibition, while those higher than $10 \mathrm{mM}\left(K_{\mathrm{SS}}\right.$, enzyme-substrate dissociation constant for complex formed at the allosteric site) indicate a non-competitive one [27]. Therefore, looking at the slopes (Figure 5) and $K_{\mathrm{S}}$ values determined for oximes C1, C2, and C3 (ranging from 0.4-0.96 mM for $\mathrm{hAChE}$ and 1.05-1.5 $\mathrm{mM}$ for $\mathrm{hBChE}$ ), we can say that the predominant type is mixed inhibition marked by binding at both the catalytic and the allosteric part of the cholinesterases active site. The strongest binding to both enzymes was observed for oxime C3, which had additional benzyl group attached to the quinuclidine ring, as was estimated from the reactivation experiments. This oxime also showed the lowest selectivity between the two enzymes. Interestingly, oxime C1 showed to be the most selective in binding and inhibited BChE about 300-fold more strongly than hAChE. Such a preference for binding compounds like $\mathrm{C} 1$ without permanent charge could benefit the development of selective inhibitors for condition where such inhibition is a proposed way of treatment as it is the case with neurodegenerative diseases [28-30]. Hence, the C1 scaffold could be used for structure refinement in the future.

Table 2. Reversible inhibition of $\mathrm{hAChE}$ and $\mathrm{hBChE}$ by the tested oximes. Dissociation inhibition constants $\left(K_{\mathrm{i}}\right)$ was evaluated from at least three experiments studied in 0.3-1.0 mM substrate ATCh concentration range.

\begin{tabular}{|c|c|c|c|c|}
\hline \multirow{2}{*}{ Oxime } & \multirow{2}{*}{$\begin{array}{c}\text { Concentration } \\
(\mu \mathrm{M})\end{array}$} & hAChE & hBChE & \multirow{2}{*}{ hAChE/hBChE } \\
\hline & & \multicolumn{2}{|c|}{$K_{\mathrm{i}}(\mu \mathrm{M}) \pm$ S.E. } & \\
\hline \multirow{2}{*}{$\mathrm{C} 1$} & $100-400$ & $432 \pm 52$ & - & \multirow{2}{*}{272} \\
\hline & $1-400$ & - & $1.59 \pm 0.06$ & \\
\hline \multirow{2}{*}{$\mathrm{C} 2$} & $100-400$ & $323 \pm 77$ & - & \multirow{2}{*}{29.9} \\
\hline & $10-400$ & - & $10.8 \pm 0.99$ & \\
\hline \multirow{2}{*}{$\mathrm{C} 3$} & 15-100 & $3.72 \pm 0.49$ & - & \multirow{2}{*}{5.8} \\
\hline & $0.5-25$ & - & $0.64 \pm 0.08$ & \\
\hline
\end{tabular}
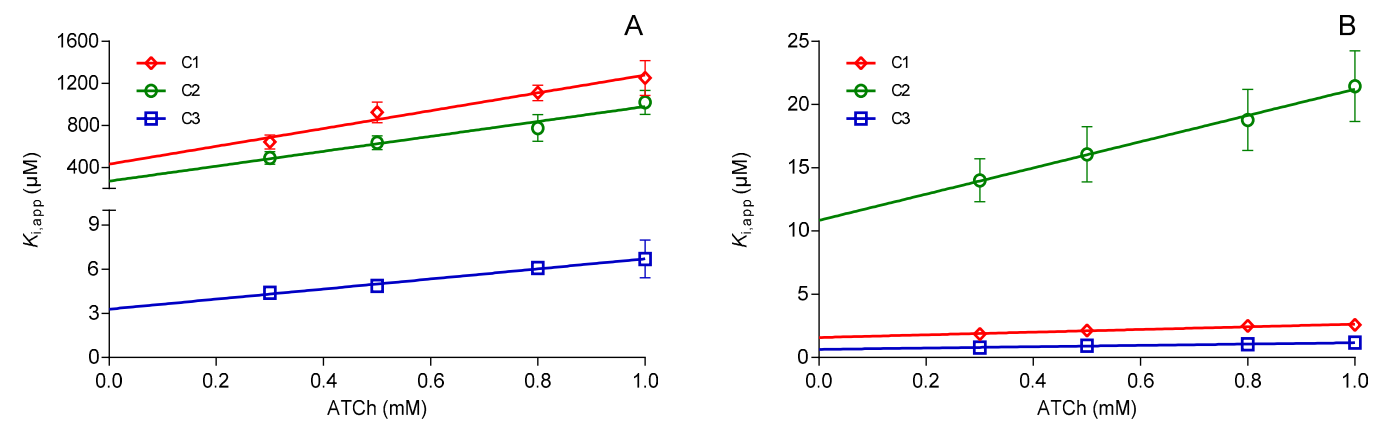

Figure 5. Reversible inhibition of (A) hAChE and (B) hBChE by the tested oximes. The graphs present Hunter-Downs plots with the average of the experimentally obtained values from at least three experiments. $K_{i}$ presenting the Y-intercept was studied in $0.3-1.0 \mathrm{mM}$ substrate acetylthiocholine (ATCh) concentration range.

Nonetheless, before being considered for any in vivo application, the compounds need to pass rigorous test spanning, much more than in in vitro kinetic studies. To profile the potential of this 
Cinchona scaffold for further development, we screened the cytotoxicity of oximes $\mathrm{C} 1, \mathrm{C} 2$, and $\mathrm{C} 3$ up to $800 \mu \mathrm{M}$ on two selected cell types: hepatocytes (Hep G2) and neurones (SH-SY5Y). The results form of $\mathrm{IC}_{50}$ graphs are presented in Figure 6. As can be seen, hepatocytes showed to be more sensitive to these oximes, especially $\mathrm{C} 1$ and $\mathrm{C} 3$. Still, the $\mathrm{IC}_{50}$ value of $\sim 800 \mu \mathrm{M}$ does not classify them as a group of highly toxic compounds [31], especially since the cholinesterase reactivation or inhibition activities of these oximes were observed at much lower concentrations. Though it would be interesting to determine and understand the mechanism behind this toxicity on the cell molecular level, this oximes scaffold proved to be acceptable for future studies, especially in view of specific cholinesterase inhibitor development. Of course, the difference between in vitro and in vivo translational variations must also be considered for further research [4].
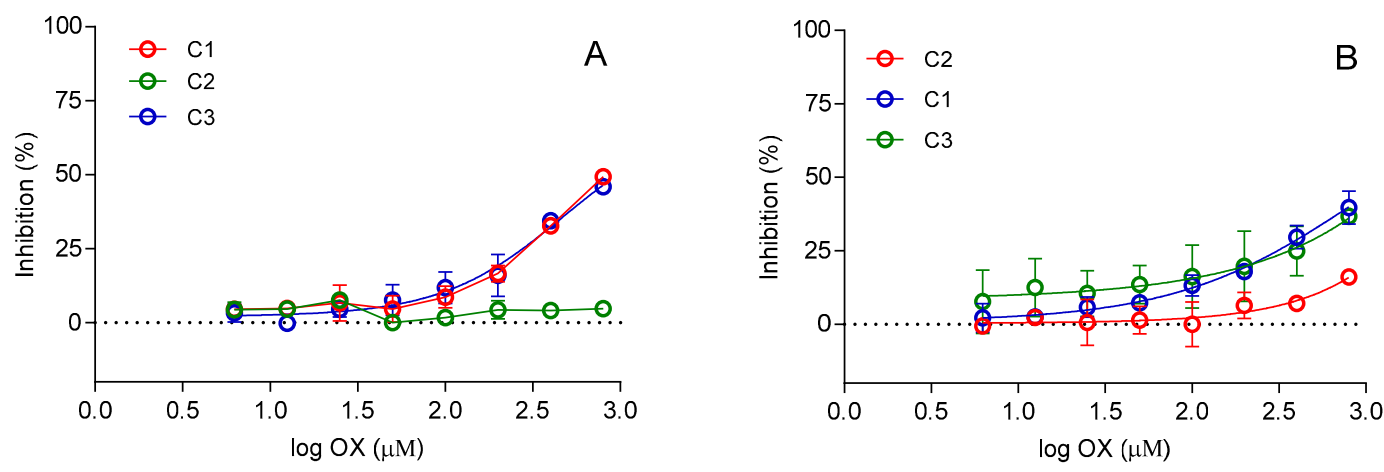

Figure 6. Cytotoxicity of oximes C1, C2, and C3 on two cell lines (A) HepG2, human Caucasian hepatocyte carcinoma, epithelial; (B) SH-SY5Y human neuroblastoma cell line.

\section{Materials and Methods}

\subsection{Synthesis of Cinchona Oximes}

All reagents and solvents were used as purchased from commercial suppliers without further purification. The reactions were monitored by thin-layer chromatography plates, Silica Gel $60 \mathrm{~F}_{254}$ plates (Merck, Darmstadt, Germany). Thin-layer chromatography (TLC) plates were visualized by ultraviolet irradiation $(254 \mathrm{~nm})$ or by iodine fumes. Melting points were determined on a Melting Point B-540 apparatus (Büchi, Essen, Germany) and are uncorrected. 1D and 2D, ${ }^{1} \mathrm{H}$ - and ${ }^{13} \mathrm{C}-\mathrm{NMR}$ spectra were recorded at $22{ }^{\circ} \mathrm{C}$ with Bruker Avance III HD $400 \mathrm{MHz} / 54 \mathrm{~mm}$ Ascend spectrometer (Bruker Optics Inc, Billerica, MA, USA). Chemical shifts are given in ppm downfield from tetramethylsilane (TMS) as an internal standard and coupling constants $(J)$ in Hz. Splitting patterns are designated as $\mathrm{s}$ (singlet), d (doublet), dd (doublet of doublets), $\mathrm{t}$ (triplet), q (quartet) or m (multiplet). Quinoline hydrogen and carbon atoms are marked with an apostrophe. High resolution mass spectra (HRMS) were obtained on a 4800 plus MALDI TOF/TOF instrument (Applied Biosystems Inc, Foster City, CA, USA).

Cinchonin-9-one: Cinchonin-9-one was synthesized according to the published procedure starting from cinchonidine ( $\geq 98.0 \%$, Sigma-Aldrich, St. Louis, MO, USA) [32]. After acid-base work up, a yellow solid was obtained. Yield: $48 \%$. m.p. $113-114{ }^{\circ} \mathrm{C}$; IR: $1698 \mathrm{~cm}^{-1}(\mathrm{C}=\mathrm{O}) ;{ }^{1} \mathrm{H}-\mathrm{NMR}(400 \mathrm{MHz}$, $\left.\mathrm{CDCl}_{3}-d\right) \delta / \mathrm{ppm} 1.47-1.63(1 \mathrm{H}, \mathrm{m}, \mathrm{H} 7 \mathrm{a}) 1.63-1.76(1 \mathrm{H}, \mathrm{m}, \mathrm{H} 4)$ 1.82-1.98 (2H, m, H5a, H7b) 2.11-2.31 (1H, m, H5b) 2.31-2.46 (1H, m, H3) 2.57-2.72 (1H, m, H2b) 2.76-2.98 (2H, m, H6) 3.04-3.26 (1H, m H2a) 4.14-4.26 (1H, m, H8) 5.02-5.18 (2H, m, H11) 5.90-6.05 (1H, m, H10) 7.59-7.64 (1H, m, H3') 7.64-7.72 (1H, m, H7') $7.77\left(1 \mathrm{H}, \mathrm{ddd}, J=8.38,7.06,1.51 \mathrm{~Hz}, \mathrm{H}^{\prime}\right) 8.18\left(1 \mathrm{H}, \mathrm{d}, J=8.29 \mathrm{~Hz}, \mathrm{H} 5^{\prime}\right) 8.20-8.29$ $\left(1 \mathrm{H}, \mathrm{m}, \mathrm{H} 8^{\prime}\right) 9.02\left(1 \mathrm{H}, \mathrm{t}, J=4.14 \mathrm{~Hz}, \mathrm{H2}{ }^{\prime}\right) ;{ }^{13} \mathrm{C}-\mathrm{NMR}\left(75 \mathrm{MHz}, \mathrm{CDCl}_{3}-d\right) \delta / \mathrm{ppm} 21.78$ (C7) 26.91 (C5) 27.38 (C4) 39.51 (C3) 49.71 (C6) 55.55 (C2) 63.33 (C8) 114.73 (C11) 119.15 (C3') 124.51 (C9') 125.05 (C5') $127.97\left(\mathrm{C}^{\prime}\right) 129.64\left(\mathrm{C}^{\prime}\right) 130.11\left(\mathrm{C} 8^{\prime}\right) 141.41(\mathrm{C} 10) 143.58\left(\mathrm{C}^{\prime}\right) 149.11\left(\mathrm{C} 10^{\prime}\right) 149.76\left(\mathrm{C} 2^{\prime}\right) 202.89$ (C=O); MALDI-HRMS $(\mathrm{m} / \mathrm{z})$ : calculated $293.1654\left(\mathrm{C}_{19} \mathrm{H}_{21} \mathrm{~N}_{2} \mathrm{O}+\mathrm{H}^{+}\right)$, found 293.1659. 
Cinchona 9-oxime (C1). Cinchonidin-9-one (1.7 mmol) and hydroxylamine hydrochloride (3.4 mmol) in ethanol $(3 \mathrm{~mL})$ were heated under reflux for $24 \mathrm{~h}$. The solvent was removed under reduced pressure. Yellow oil was dissolved in ice-cold water and $\mathrm{pH}$ adjusted to 6.5 with $5 \mathrm{M} \mathrm{NaOH}$. After extraction with ether and evaporating the solvent, Cinchona 9-oxime was purified by column chromatography on alumina with chloroform:methanol $=9: 1$ as eluent. Off-white solid. Oxime in a solution exist as a mixture of 8-(S)- and 8-(R)-epimers $(S: R=1: 2.3)$. Yield: $63 \%$; m.p. 98-99 ${ }^{\circ}$ C. IR: $1634 \mathrm{~cm}^{-1}(\mathrm{C}=\mathrm{N}-\mathrm{OH})$; (S)-epimer: ${ }^{1} \mathrm{H}-\mathrm{NMR}\left(400 \mathrm{MHz}, \mathrm{CDCl}_{3}-d\right) \delta / \mathrm{ppm}$ : $1.57(1 \mathrm{H}, \mathrm{d}, J=5.46 \mathrm{~Hz}, \mathrm{H7a}) 1.67-1.80(1 \mathrm{H}, \mathrm{m}, \mathrm{H} 4)$ 1.82-1.97 (2H, m, H7b, H5b) 2.05-2.16 (1H, m, H5a) 2.32 (1H, s, H3) 2.60-2.85 (2 H, m, H2) 3.04-3.34 (2H, m, H6) 3.66-3.79 (1H, m, H8) 4.97-5.12 (2H, m, H11) 5.80-5.96 (1H, m, H10) 7.21-7.28 (1H, m, $\left.\mathrm{H3}^{\prime}\right)$ 7.46-7.63 (1H, m, H7') 7.65-7.80 (2H, m, H5' , H6 $\left.{ }^{\prime}\right)$ 8.13-8.23 (1H, m, H8') 8.87-8.99 (1H, m, H2'); ${ }^{13} \mathrm{C}-\mathrm{NMR}$ (101 MHz, CDCl $\mathrm{C}_{3}$-d) $\delta / \mathrm{ppm}: 23.02$ (C5) 27.67 (C7) 27.73 (C4) 39.67 (C3) 41.92 (C6) 55.64 (C2) 59.90 (C8) 114.50 (C11) $118.64\left(\mathrm{C}^{\prime}\right) 119.91\left(\mathrm{C}^{\prime}\right) 124.68\left(\mathrm{C}^{\prime}\right) 126.94\left(\mathrm{C}^{\prime}\right) 129.41\left(\mathrm{C}^{\prime}\right) 130.09\left(\mathrm{C}^{\prime}\right) 141.76$ (C10) $141.92\left(\mathrm{C}^{\prime}\right) 148.04\left(\mathrm{C} 10^{\prime}\right) 149.91\left(\mathrm{C} 2^{\prime}\right) 155.12$ (C=N); (R)-epimer: ${ }^{1} \mathrm{H}-\mathrm{NMR}\left(400 \mathrm{MHz}, \mathrm{CDCl}_{3}-d\right)$

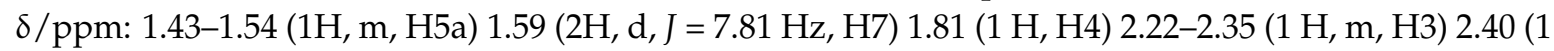
$\mathrm{H}, \mathrm{dd}, J=13.07,9.17 \mathrm{~Hz}, \mathrm{H} 5 \mathrm{~b})$ 2.72-2.93 (3 H, m, H2, H6a) 2.93-3.11 (1H, m, H6b) 3.61-3.73 (1H, m, H8) 5.00-5.11 (2H, m, H11) 5.94-6.06 (1H, m, H10) 7.15-7.25 (1 H, m, H3 $\left.{ }^{\prime}\right)$ 7.47-7.57 (1H, m, H7') 7.59-7.72 $\left(2 \mathrm{H}, \mathrm{m}, \mathrm{H}^{\prime}, \mathrm{H}^{\prime}\right)$ 8.12-8.23 ( H, m, H8 $\left.{ }^{\prime}\right) 8.80\left(1 \mathrm{H}, \mathrm{d}, \mathrm{J}=4.29 \mathrm{~Hz}, \mathrm{H} 2^{\prime}\right) ;{ }^{13} \mathrm{C}-\mathrm{NMR}\left(101 \mathrm{MHz}, \mathrm{CDCl}_{3}-d\right)$ ઠ/ppm: 23.15, 23.77 (C5) 26.44 (C7) 28.03 (C4) 40.14, 40.30 (C3) 48.07, 48.52 (C6) 48.76, 48.93 (C2) 59.68, 60.54 (C8) 114.60 (C11) $118.57\left(\mathrm{C}^{\prime}\right) 120.22\left(\mathrm{C}^{\prime}\right)$ 124.94, $125.63\left(\mathrm{C} 9^{\prime}\right) 125.35\left(\mathrm{C}^{\prime}\right)$ 126.57, $126.65\left(\mathrm{C} 6^{\prime}\right)$ 129.39, $129.82\left(\mathrm{C}^{\prime}\right)$ 140.44, 140.56 (C10) 142.75, $143.71\left(\mathrm{C}^{\prime}\right)$ 147.71, $147.78\left({\left.\mathrm{C} 10^{\prime}\right)}^{\prime}\right)$ 149.61, $149.77\left(\mathrm{C} 2^{\prime}\right)$ 153.46, $153.97(\mathrm{C}=\mathrm{N})$; MALDI-HRMS $(\mathrm{m} / z)$ : calculated $308.1763\left(\mathrm{C}_{19} \mathrm{H}_{22} \mathrm{~N}_{3} \mathrm{O}+\mathrm{H}^{+}\right)$, found 308.1751.

N-Methyl-9-hydroxyiminocinchonium iodide (C2). A solution of Cinchona 9-oxime (0.31 mmol) and methyl iodide $(0.32 \mathrm{mmol})$ in dry acetone was heated in reflux and reaction was monitored with TLC. Solvent was evaporated under reduced pressure and yellow oil was washed with ether three times. Yellow solid. Yield: $81 \%$; m.p. $140{ }^{\circ} \mathrm{C}$ decomp. IR: $1634 \mathrm{~cm}^{-1}(\mathrm{C}=\mathrm{N}-\mathrm{OH}) ;{ }^{1} \mathrm{H}-\mathrm{NMR}(400 \mathrm{MHz}$, DMSO- $d_{6}$ ) $\delta /$ ppm: 2.0-2.1 (5H, m, $\left.\mathrm{CH}_{3}, \mathrm{H} 7\right)$ 2.11-2.25 (1H, m, H4) 2.29-2.42 (1H, m, H5a) 2.83-2.96 (2 H, m, H5b, H3) 3.46-3.73 (2H, m, H2) 3.73-3.89 (1H, m, H6b) 3.97-4.20 (1H, m, H6a) 4.54-4.80 (1H, m H8) 5.11-5.35 (2H, m, H11) 5.81-6.10 (1H, m, H10) 7.53-7.62 (1H, m, H3') 7.63-7.77 (2H, m, H7' , H6') 7.79-7.88 (1H, m, H5') 8.09-8.15 (1H, m, H8 $)$ 9.04(1H, dd, J = 4.28, 3.06 Hz, H2'); ${ }^{13} \mathrm{C}-\mathrm{NMR}(101 \mathrm{MHz}$, DMSO- $d_{6}$ ) $\delta /$ ppm: 25.04 (C5) 26.90 (C4) 27.92 (C7) $31.22\left(\mathrm{CH}_{3}\right) 37.62$ (C3) 53.23 (C6) 59.48 (C2) 68.06 (C8) 117.65 (C11) $120.67\left(\mathrm{C}^{\prime}\right) 124.50\left(\mathrm{C}^{\prime}\right) 125.26\left(\mathrm{C}^{\prime}\right) 127.58\left(\mathrm{C}^{\prime}\right) 128.15\left(\mathrm{C}^{\prime}\right) 130.26\left(\mathrm{C}^{\prime}\right) 138.13$ (C10) $140.47\left(\mathrm{C}^{\prime}\right) 148.31\left(\mathrm{C} 10^{\prime}\right) 150.42(\mathrm{C}=\mathrm{N}) 150.73(\mathrm{C} 2)$; MALDI-HRMS (m/z): calculated 322.1914 $\left(\mathrm{C}_{20} \mathrm{H}_{24} \mathrm{~N}_{3} \mathrm{O}^{+}\right)$, found 322.1918 .

N-Benzyl-9-hydroxyiminocinchonium bromide (C3). A solution of the Cinchona 9-oxime (0.25 mmol) and benzyl bromide $(0.26 \mathrm{mmol})$ in dry acetone was heated in reflux and the reaction was monitored with TLC. The solvent was evaporated under reduced pressure and orange oil was washed with ether three times. Orange solid. Yield: $69 \%$; m.p. $170{ }^{\circ} \mathrm{C}$ decomp. IR: $1634 \mathrm{~cm}^{-1}(\mathrm{C}=\mathrm{N}-\mathrm{OH}) ;{ }^{1} \mathrm{H}-\mathrm{NMR}(400 \mathrm{MHz}$, DMSO- $\left.d_{6}\right) \delta /$ ppm: 1.82-1.94 (2H, m, H7) 1.94-2.23 (2H, m, H4, H5a) 2.34-2.39 (1H, m, H5b) 2.72-2.83 (1H, m, H3) 3.43-3.65 (2H, m, H2) 3.81-3.98 (1H, m, H6b) 4.09-4.27 (1H, m, H6a) 4.66-4.80 (1H, m, H8) 4.81-5.09 (2 H, m, CH $)$ 5.19-5.38 (2 H, m, H11) 5.83-6.08 (1H, m, H10) 7.45-7.49 (1H, m, H3') 7.53-7.65 $(5 \mathrm{H}, \mathrm{m}, \mathrm{Ar}) 7.72-7.80\left(2 \mathrm{H}, \mathrm{m}, \mathrm{H}^{\prime}, \mathrm{H}^{\prime}\right)$ 7.84-7.98 (1H, m, H6 $)$ 8.06-8.17 (1H, m, H8'), 8.99-9.11 (1H, m, H2'); ${ }^{13}$ C-NMR (101 MHz, DMSO-d 6 ) $\delta /$ ppm: 24.46 (C5) 26.98 (C4) 28.46 (C7) 37.30 (C3) 55.83 (C6) $59.90(\mathrm{C} 2) 65.39\left(\mathrm{CH}_{2}\right) 66.93(\mathrm{C} 8) 117.64(\mathrm{C} 11) 121.37\left(\mathrm{C}^{\prime}\right) 124.73\left(\mathrm{C}^{\prime}\right) 125.73\left(\mathrm{C}^{\prime}\right) 127.57\left(\mathrm{C} 4^{*}\right) 128.05$ (C6') $128.11\left(\mathrm{C}^{*}\right) 129.56\left(\mathrm{C}^{*}, \mathrm{C}^{*}\right) 130.27\left(\mathrm{C}^{\prime}\right) 130.73\left(\mathrm{C}^{\prime}\right) 134.04\left(\mathrm{C}^{*}, \mathrm{C}^{*}\right) 137.43(\mathrm{C} 10) 140.22\left(\mathrm{C}^{\prime}\right)$ $148.25\left(\mathrm{C} 10^{\prime}\right) 150.73\left(\mathrm{C}^{\prime}\right) 150.41(\mathrm{C}=\mathrm{N})$; MALDI-HRMS $(\mathrm{m} / \mathrm{z})$ : calculated $398.2227\left(\mathrm{C}_{26} \mathrm{H}_{28} \mathrm{~N}_{3} \mathrm{O}^{+}\right)$, found 398.2234 . 


\subsection{Quantum Chemical Calculations}

All quantum chemical calculations were carried out using Gaussian 09 [33]. Geometry optimizations and harmonic frequency calculations were performed using density functional theory with B3LYP functional and 6-311++G(d,p) basis set. Afterward, magnetic isotropic shieldings were calculated at the same level of the theory. NMR spectra were estimated relative to tetramethylsilane.

\subsection{Chemicals}

The synthesized Cinchona oximes were dissolved in DMSO as 100 mM. Paraoxon-ethyl was purchased from Sigma-Aldrich, while sarin, cyclosarin, tabun and VX from NC Laboratory (Spiez, Switzerland). Stock solutions of sarin, cyclosarin, tabun and VX $(5000 \mu \mathrm{g} / \mathrm{mL})$ were prepared in isopropyl alcohol and further dilutions were made in water at $10^{-5} \mathrm{M}$ just before use, except paraoxon, which was diluted in ethanol. OPs were used in accordance with safe use and safe disposition of highly toxic compounds. ATCh and thiol reagent 5,5'-dithiobis(2-nitrobenzoic acid) (DTNB) were purchased from Sigma-Aldrich (St. Louis, MO, USA). Stock solutions were prepared in water or $0.1 \mathrm{M}$ sodium phosphate buffer $\mathrm{pH}$ 7.4. The final concentration of ATCh in reactivation experiments was $1.0 \mathrm{mM}$. The final concentration of DTNB was $0.33 \mathrm{mM}$ for all activity measurements at $25^{\circ} \mathrm{C}$. Enzymes, recombinant human AChE and purified human plasma BChE, were a gift from Dr. Florian Nachon (Institut de Recherche Biomédicale des Armées, Brétigny-sur-Orge, France). MTS reagent [3-(4,5-dimethylthiazole-2-yl)-2,5-diphenyl tetrazolium bromide] for cytotoxicity assays was purchased from Promega (Madison, WI, USA).

\section{4. $p K_{a}$ Determination}

Acid dissociation constant $\left(K_{\mathrm{a}}\right)$ of the oxime group was determined by measuring the degradation of ATCh $(1 \mathrm{mM})$ by $100 \mu \mathrm{M}$ oxime (oximolysis) at $412 \mathrm{~nm}$ and in $\mathrm{pH}$ range $4.4-11.3$ (0.1 M phosphate buffer; $\mathrm{pH}<9.25$ was prepared with $0.2 \mathrm{M} \mathrm{NaOH}$ ) as described previously (20). $\mathrm{p} K_{\mathrm{a}}$ values were calculated using the modified equation described previously [34]:

$$
v=k \cdot[\text { ATCh }] \cdot[\text { oxime }] \cdot\left(\frac{K_{a}}{K_{a}+\left[\mathrm{H}^{+}\right]}\right)^{n}
$$

where $v$ is the rate of oximolysis, $k$ is oximolysis constant and $n$ is Hill coefficient. Oximolysis was measured in triplicates and corrected for spontaneous degradation of ATCh and DTNB at different $\mathrm{pH}$.

Since the acid-base equilibrium of other functional groups may interfere with the $\mathrm{p} K_{\mathrm{a}}$ determination from oximolysis (as seen from the Hill coefficients if $n<1$ ), $\mathrm{p} K_{\mathrm{a}}$ values were also predicted in silico using Marvin software (version 16.11.7.0, ChemAxon, Budapest, Hungary). In such a way in silico determined $\mathrm{p} K_{\mathrm{a}}$ values of the oxime group will serve as a confirmation of the $\mathrm{p} K_{\mathrm{a}}$ values of the oxime group determined in vitro.

\subsection{Determination of Oxime Inhibition Constants}

To determine enzyme-oxime dissociation constant $K_{\mathrm{i}}$ (the concentration of an oxime at which it inhibits $50 \%$ of enzyme activity), we measured the enzymes' activity in the presence of a wide range of oximes' concentrations ensuring 20-80\% inhibition compared to the control activity. The assay was performed in the 96 well-plates on the Tecan Infinite M200PRO plate reader (Tecan Austria $\mathrm{GmbH}$, Salzburg, Austria). The inhibition mixture (300 $\mu \mathrm{L}$ final) contained a buffer, enzyme (AChE, $0.3 \mathrm{nM}$ or BChE, $2.8 \mathrm{nM}$ ), oxime and DTNB (0.33 mM final), and after the addition of ATCh (1.0 mM final), the activity was assayed by Ellman's method [35]. Each oxime-substrate pair was measured in duplicate. For oximes dissolved in DMSO, the final DMSO concentration was kept under $0.5 \%$ to eliminate its influence on enzyme activity. The measured activity was corrected for the oxime-induced hydrolysis of ATCh. The $K_{\mathrm{i}}$ values were determined from experimental points obtained from at least 
two experiments using the Prismsoftware (Version 6, Graph Pad Software, San Diego, CA, USA) and were evaluated from the effect of substrate concentration $(s)$ on the degree of inhibition according to the Hunter-Downs equation [36]:

$$
K_{\mathrm{app}}=\frac{v_{\mathrm{i}} \cdot i}{v_{\mathrm{O}}-v_{\mathrm{i}}}=K_{(\mathrm{I})}+\frac{K_{(\mathrm{I})}}{K_{(\mathrm{S})}} \cdot s
$$

where $K_{\mathrm{app}}$ is the apparent enzyme-oxime dissociation constant at a given substrate concentration $(s)$, calculated from the enzyme activities $v_{0}$ and $v_{i}$ measured in the absence and in the presence of the oxime $(i)$, respectively. $K_{(I)}$ is the enzyme-oxime dissociation constant of a complex formed in the catalytic site $\left(K_{\mathrm{i}}\right)$ or allosteric site constant $\left(K_{\mathrm{i}}{ }^{\prime}\right) . K_{(\mathrm{S})}$ is the enzyme-substrate dissociation constant corresponding to the Michaelis constant $\left(K_{\mathrm{M}}\right)$ or to the substrate inhibition constant $\left(K_{\mathrm{ss}}\right)$. The values of $K_{(\mathrm{I})}$ and $K_{(\mathrm{S})}$ were intercepts of the line on the ordinate and abscissa, respectively. When the plot is non-linear function of $s$, the oxime binds to both the catalytic and peripheral allosteric site. $K_{\mathrm{i}}$ is then obtained from the initial linear part of the curve at the lower substrate concentrations. Since $1.0 \mathrm{mM}$ ATCh was the highest concentration used, the $K_{\mathrm{i}}{ }^{\prime}$ from the higher substrate concentration range was not determined.

\subsection{Oxime-Assisted Reactivation of OP-Inhibited Cholinesterases}

Recombinant human AChE and purified human plasma BChE were incubated with all of the OPs $\left(10^{-5} \mathrm{M}\right)$ up to $1 \mathrm{~h}$, achieving $95-100 \%$ inhibition. The inhibited enzymes were passed through a Strata C18-E column (Phenomenex, Torrance, CA, USA) to remove the excess of unconjugated OP. After filtration, the enzyme was incubated with $0.1 \mathrm{mM}$ oximes (or $0.05 \mathrm{mM}$ oxime $\mathrm{C} 3$ ) and at specified time intervals (up to $24 \mathrm{~h}$ ), an aliquot was taken and diluted 40 -fold in buffer containing DTNB. Enzymes concentration in the reactivation mixture were $0.016 \mu \mathrm{M}$ for $\mathrm{AChE}$ and $0.122 \mu \mathrm{M}$ for BChE. The recovered enzyme activity was measured upon addition of the substrate ATCh $(1 \mathrm{mM})$ by the Ellman method [35]. More precisely, at least 10 experimental points of reactivation were obtained within $24 \mathrm{~h}$. An equivalent sample of the uninhibited enzyme was passed through a parallel column, diluted to the same extent as the inhibition mixture, and control activity was measured in the presence of the oxime at concentrations used for reactivation. Both the activities of the control and the reactivation mixture were corrected for oxime-induced hydrolysis of ATCh. No spontaneous reactivation occurred. Enzyme activity measurements were performed at $25^{\circ} \mathrm{C}$ and $412 \mathrm{~nm}$, on the CARY 300 spectrophotometer (Varian Inc., Mulgrave, Australia) with a temperature controller. The reactivation screening was done at a given oxime concentration wherefrom the observed first-order reactivation rate constant $\left(k_{\mathrm{obs}}\right)$ and maximal reactivation (React max $_{\text {) }}$ were determined as previously described [17] from experimental points obtained from at least two experiments using the Prism software (Version 6, Graph Pad Software, San Diego, CA, USA).

\subsection{Cytotoxicity Screening}

Cells for oxime cytotoxicity profiling were procured from the American Type Culture Collection (Rockville, MD, USA): Human Caucasian hepatocyte carcinoma (HepG2, ATCC HB8065) and from European Collection of Authenticated Cell Cultures (Salisbury, England, UK): Human neuroblastoma (SH-SY5Y, ECACC 94030304). SH-SY5Y were grown in Dulbecco's modified Eagle's medium F12 (DMEM, Sigma-Aldrich, Steinheim, Germany) supplemented with 15\% fetal bovine serum (Gibco, Paisley, UK), 2 mM glutamine, 1\% non-essential amino acids and HepG2 were grown in Eagle's Minimum Essential Medium with Earle's salts and sodium bicarbonate, without L-glutamine (EMEM) supplemented with $10 \%(v / v)$ fetal bovine serum (Gibco, Paisley, UK) at $37{ }^{\circ} \mathrm{C}$ in a $5 \% \mathrm{CO}_{2}$ atmosphere, according to the manufacturer's instructions. Cells were detached with $0.25 \%$ Trypsin/EDTA solution (Sigma-Aldrich, St. Louis, MO, USA), re-suspended and seeded at 96-well for experiments. Cells were treated and exposed for $24 \mathrm{~h}$ to Cinchona oximes $(6.25-800 \mu \mathrm{M})$. Cytotoxicity was determined using 
the standard MTS detection reagent assay measuring the succinate dehydrogenase mitochondrial activity of living cells [37]. Procedure followed a previously described protocol [24]. Cells and oximes were incubated for $24 \mathrm{~h}$ at $37^{\circ} \mathrm{C} .120 \mu \mathrm{L}$ of MTS mix reagent (CellTiter 96 AQueous One Solution Cell Proliferation Assay, Promega, Madison, WI, USA) was added in each well incubated 0.5-3 h (different cell lines) after which the absorbance was read at $492 \mathrm{~nm}$ on a Tecan Infinite M200PRO plate reader. Total percentage of DMSO in cytotoxicity assay was $0.8 \%$. The assay was performed in 96-well in $120 \mu \mathrm{L}$ /well media volume with 100,000 or 400,000 cells. Data was evaluated using predefined $\mathrm{IC}_{50}$ equation from the Graph Pad Prism programme.

\section{Conclusions}

We evaluated a new Cinchona structure scaffold as a potential way forward in the development of more efficient treatment in OP poisoning. Though, they were poor AChE reactivators they showed somewhat promising results in BChE reactivation in terms of their observed universal activity against various OPs. Furthermore, they were shown to be a good starting structure for development of selective ligands with high affinity for binding to the active site of BChE. Future studies of such compounds were also supported by cytotoxicity results as long as their biological activity was targeted in the lower micromolar range.

Supplementary Materials: The following are available online, Figure S1: Time-dependent course of reactivation of hBChE, Figure S2: Atom numbering of Cinchona alkaloid derivatives, Figures S3-S14: IR, 1H and 13C NMR spectra of prepared compounds, Tables S1-S3: Quantum-chemical calculations.

Acknowledgments: We are grateful to Tomica Hrenar for his valuable help in performing quantum-chemical calculations. We also thank Chistophe Curty for helpful assistance with purchasing organophosphates, Florian Nachon for the human recombinant AChE and human purified BChE, and Makso Herman for language editing. This study was supported by the Croatian Science Foundation (HrZZ 4307).

Author Contributions: A.R. and I.P. designed and synthesized the oximes. M.K. and Z.K. conceived and designed the experiments. A.Z., T.Z., and M.K. performed the experiments and analyzed the data. M.K., A.Z., A.R., T.Z., I.P and Z.K. contributed to writing the paper.

Conflicts of Interest: The authors declare no conflict of interest.

\section{References}

1. Bajgar, J. Organophosphates/nerve agent poisoning: Mechanism of action, diagnosis, prophylaxis and treatment. Adv. Clin. Chem. 2004, 38, 151-216. [PubMed]

2. Stojiljković, M.P.; Jokanović, M. Pyridinium oximes: Rationale for their selection as causal antidotes against organophosphate poisonings and current solutions for auto-injectors. Arh. Hig. Rada Toksikol. 2006, 57, 435-443. [PubMed]

3. Worek, F.; Thiermann, H.; Wille, T. Oximes in organophosphate poisoning: 60 years of hope and despair. Chem. Biol. Interact. 2016, 259, 93-98. [CrossRef] [PubMed]

4. Katalinić, M.; Maček Hrvat, N.; Ždarova Karasova, J.; Misik, J.; Kovarik, Z. Translation of in vitro to in vivo pyridinium oxime potential in tabun poisoning. Arh. Ind. Hig. Rada Toxicol. 2015, 66, 285-292.

5. Kovarik, Z.; Radić, Z.; Berman, H.A.; Simeon-Rudolf, V.; Reiner, E.; Taylor, P. Mutant cholinesterases possessing enhanced capacity for reactivation of their phosphonylated conjugates. Biochemistry 2004, 43, 3222-3229. [CrossRef] [PubMed]

6. Kovarik, Z.; Čalić, M.; Šinko, G.; Bosak, A.; Berend, S.; Lucić Vrdoljak, A.; Radić, B. Oximes: Reactivators of phosphorylated acetylcholinesterase and antidotes in therapy against tabun poisoning. Chem. Biol. Interact. 2008, 175, 173-179. [CrossRef] [PubMed]

7. Worek, F.; Thiermann, H. The value of novel oximes for treatment of poisoning by organophosphorus compounds. Pharmacol. Ther. 2013, 139, 249-259. [CrossRef] [PubMed]

8. Renou, J.; Loiodice, M.; Arboléas, M.; Baati, R.; Jean, L.; Nachon, F.; Renard, P.Y. Tryptoline-3-hydroxypyridinaldoxime conjugates as efficient reactivators of phosphylated human acetyl and butyrylcholinesterases. Chem. Commun. 2014, 50, 3947-3950. [CrossRef] [PubMed] 
9. De Koning, M.C.; van Grol, M.; Noort, D. Peripheral site ligand conjugation to a non-quaternary oxime enchances reactivation of nerve agent-inhibited human acetylcholinesterase. Toxicol. Lett. 2011, 206, 54-59. [CrossRef] [PubMed]

10. Radić, Z.; Sit, R.K.; Garcia, E.; Zhang, L.; Berend, S.; Kovarik, Z.; Amitai, G.; Fokin, V.V.; Sharpless, K.B.; Taylor, P. Mechanism of interaction of novel uncharged, centrally active reactivators with OP-hAChE conjugates. Chem. Biol. Interact. 2013, 203, 67-71. [CrossRef] [PubMed]

11. Kovarik, Z.; Maček, N.; Sit, R.K.; Radić, Z.; Fokin, V.V.; Sharpless, K.B.; Taylor, P. Centrally acting oximes in reactivation of tabun-phosphoramidated AChE. Chem. Biol. Interact. 2013, 203, 77-80. [CrossRef] [PubMed]

12. Mercey, G.; Verdelet, T.; Renou, J.; Kliachyna, M.; Baati, R.; Nachon, F.; Jean, L.; Renard, P.-Y. Reactivators of acetylcholinesterase inhibited by organophosphorus nerve agents. Acc. Chem. Res. 2012, 45, 756-766. [CrossRef] [PubMed]

13. Karlsson, D.; Fallarero, A.; Shinde, P.; Anju, C.P.; Busygin, I.; Leino, R.; Mohan, C.G.; Vuorela, P. Chemical modifications of Cinchona alkaloids lead to enhanced inhibition of human butyrylcholinesterase. Nat. Prod. Commun. 2014, 9, 455-458. [PubMed]

14. Nawaz, S.A.; Ayaz, M.; Brandt, W.; Wessjohann, L.A.; Westermann, B. Cation $-\pi$ and $\pi-\pi$ stacking interactions allow selective inhibition of butyrylcholinesterase by modified quinine and cinchonidine alkaloids. Biochem. Biophys. Res. Commun. 2011, 404, 935-940. [CrossRef] [PubMed]

15. Robins, R.J.; Rhodes, M.J.C. An evaluation of the tautomerism of cinchoninone and quinidinonemade using a combination of ${ }^{1} \mathrm{H}-\mathrm{NMR}$ and ${ }^{13} \mathrm{C}-\mathrm{NMR}$ spectroscopy. Phytochemistry 1987, 26, 551-556. [CrossRef]

16. Sit, R.K.; Fokin, V.V.; Amitai, G.; Sharpless, K.B.; Taylor, P.; Radić, Z. Imidazole aldoximes effective in assisting butyrylcholinesterase catalysis of organophosphate detoxification. J. Med. Chem. 2014, 57, 1378-1389. [CrossRef] [PubMed]

17. Katalinić, M.; Hrvat, N.M.; Baumann, K.; Morasi Piperčić, S.; Makarić, S.; Tomić, S.; Jović, O.; Hrenar, T.; Miličević, A.; Jelić, D.; et al. A comprehensive evaluation of novel oximes in creation of butyrylcholinesterase-based nerve agent bioscavengers. Toxicol. Appl. Pharmacol. 2016, 310, 195-204. [CrossRef] [PubMed]

18. Kovarik, Z.; Katalinić, M.; Šinko, G.; Binder, J.; Holas, O.; Jung, Y.S.; Musilova, L.; June, D.; Kuča, K. Pseudo-catalytic scavenging: Searching for a suitable reactivator of phosphorylated butyrylcholinesterase. Chem. Biol. Interact. 2010, 187, 167-171. [CrossRef] [PubMed]

19. Sit, R.K.; Radić, Z.; Gerardi, V.; Zhang, L.; Garcia, E.; Katalinić, M.; Amitai, G.; Kovarik, Z.; Fokin, V.V.; Sharpless, K.B.; et al. New structural scaffolds for centrally acting oxime reactivators of phosphylated cholinesterases. J. Biol. Chem. 2011, 286, 19422-19430. [CrossRef] [PubMed]

20. Radić, Z.; Dale, T.; Kovarik, Z.; Berend, S.; Garcia, E.; Zhang, L.; Amitai, G.; Green, C.; Radić, B.; Duggan, B.M.; et al. Catalytic detoxification of nerve agent and pesticide organophosphates by butyrylcholinesterase assisted with non-pyridinium oximes. Biochem. J. 2013, 450, 231-242. [CrossRef] [PubMed]

21. Horn, G.; Wille, T.; Musilek, K.; Kuca, K.; Thiermann, H.; Worek, F. Reactivation kinetics of 31 structurally different bispyridinium oximes with organophosphate-inhibited human butyrylcholinesterase. Arch. Toxicol. 2015, 89, 405-414. [CrossRef] [PubMed]

22. Čalić, M.; Vrdoljak, A.L.; Radić, B.; Jelić, D.; Jun, D.; Kuča, K.; Kovarik, Z. In vitro and in vivo evaluation of pyridinium oximes: Mode of interaction with acetylcholinesterase, effect on tabun- and soman-poisoned mice and their cytotoxicity. Toxicology 2006, 219, 85-96. [CrossRef] [PubMed]

23. Kovarik, Z.; Čalić, M.; Bosak, A.; Šinko, G.; Jelić, D. In vitro evaluation of aldoxime interactions with human acetylcholinesterase. Croat. Chem. Acta 2008, 81, 47-57.

24. Odžak, R.; Čalić, M.; Hrenar, T.; Primožič, I.; Kovarik, Z. Evaluation of newly synthesized monoquaternary pyridinium oximes potency to reactivate tabun-phosphorylated acetylcholinesterase. Toxicology 2007, 233, 85-96. [CrossRef] [PubMed]

25. Čalić, M.; Bosak, A.; Kuča, K.; Kovarik, Z. Interactions of butane, but-2-ene or xylene-like linked bispyridinium para-aldoximes with native and tabun-inhibited human cholinesterases. Chem. Biol. Interact. 2008, 175, 305-308. [CrossRef] [PubMed]

26. Simeon-Rudolf, V.; Šinko, G.; Štuglin, A.; Reiner, E. Inhibition of human blood acetylcholinesterase and butyrylcholinesterase by ethopropazine. Croat. Chem. Acta 2001, 74, 173-182. 
27. Kovarik, Z.; Radić, Z.; Berman, H.A.; Simeon-Rudolf, V.; Reiner, E.; Taylor, P. Acetylcholinesterase active centre and gorge conformations analyzed by combinatorial mutations and enantiomeric phosphonates. Biochem. J. 2003, 373, 33-40. [CrossRef] [PubMed]

28. Katalinić, M.; Rusak, G.; Domaćinović Barović, J.; Šinko, G.; Jelić, D.; Antolović, R.; Kovarik, Z. Structural aspects of flavonoids as inhibitors of human butyrylcholinesterase. Eur. J. Med. Chem. 2010, 45, 186-192. [CrossRef] [PubMed]

29. Bosak, A.; Gazić Smilović, I.; Vinković, V.; Šinko, G.; Kovarik, Z. Metaproterenol, isoproterenol and their bisdimethylcarbamate derivatives as human cholinesterase inhibitors. J. Med. Chem. 2012, 55, 6716-6723. [CrossRef] [PubMed]

30. Greig, N.H.; Utsuki, T.; Yu, Q.-S.; Zhu, X.; Holloway, H.W.; Perry, T.A.; Lee, B.; Ingram, D.K.; Lahiri, D.H. A new therapeutic target in Alzheimer's disease treatment: Attention to butyrylcholinesterase. Curr. Med. Res. Opin. 2001, 17, 2159-2165. [CrossRef]

31. Organisation for Economic Co-operation and Development (OECD). Guidance Document on Using Cytotoxicity Test to Estimate Starting Doses for Acute Oral Systemic Toxicity; ENV/JM/MONO(2010)20; OECD: Paris, France, 2010.

32. Pettit, G.R.; Gupta, S.K. Structural biochemistry. Part 8. 9-amino-(9-deoxy)-Cinchona alkaloids. J. Chem. Soc. Perk. T. 1 1968, 10, 1208-1213. [CrossRef]

33. Frisch, M.J.; Trucks, G.W.; Schlegel, H.B.; Scuseria, G.E.; Robb, M.A.; Cheeseman, J.R.; Scalmani, G.; Barone, V.; Mennucci, B.; Petersson, G.A.; et al. Gaussian 09, Revision A.02; Gaussian, Inc.: Wallingford, CT, USA, 2009.

34. Šinko, G.; Čalić, M.; Bosak, A.; Kovarik, Z. Limitation of the Ellman method: Cholinesterase activity measurement in the presence of oximes. Anal. Biochem. 2007, 370, 223-227. [CrossRef] [PubMed]

35. Ellman, G.L.; Courtney, K.D.; Andres, V., Jr.; Featherstone, R.M. New and rapid colorimetric determination of acetylcholinesterase activity. Biochem. Pharmacol. 1961, 7, 88-95. [CrossRef]

36. Kovarik, Z.; Ciban, N.; Radić, Z.; Simeon-Rudolf, V.; Taylor, P. Active site mutant acetylcholinesterase interactions with 2-PAM, HI-6, and DDVP. Biochem. Biophys. Res. Commun. 2006, 342, 973-978. [CrossRef] [PubMed]

37. Mosmann, T. Rapid colorimetric assay for cellular growth and survival: Application to proliferation and cytotoxicity assays. J. Immunol. Methods 1983, 65, 55-63. [CrossRef]

Sample Availability: Samples of the compounds are available from the authors.

(C) 2017 by the authors. Licensee MDPI, Basel, Switzerland. This article is an open access article distributed under the terms and conditions of the Creative Commons Attribution (CC BY) license (http://creativecommons.org/licenses/by/4.0/). 